\title{
The convergence of stroke and dementia
}

\author{
A convergência do acidente vascular cerebral e da demência
}

Vladimir Hachinski ${ }^{1}$

\begin{abstract}
Neurological disorders account for the most Disability Adjusted Life Years (DALY's) - of the Global Burden of Disease (10\%). More than half of neurological DALY's result from the combination of stroke (42\%) and dementia (10\%). The two pose risk for each other and share the same predisposing factors. A stroke doubles the risk of dementia. The close interactions call for convergent approaches. Stroke and dementia also converge at the microscopic level. The neurovascular unit has emerged as a key organizational structure of the brain. Involvement of any of its elements affects all the others. Thus, neurodegeneration impairs the microcirculation and disturbances of the microcirculation accelerate neurodegeneration. Evolving technologies allow "in vivo" imaging of the usual mixture of vascular and neurodegenerative pathology of the elderly that makes them prone to stroke and dementia. Since they occur together, they should be prevented together with a multimodal approach of lifestyle changes and mechanistic therapeutic targets. The two fields are also converging at the policy level. The World Stroke Organization has updated its Proclamation to include potentially preventable dementias that has been endorsed by Alzheimer Disease International, The World Federation of Neurology, the American Academy of Neurology and 20 international, regional and national organizations. Those interested in stroke and those dealing with dementia should work together where they can, differ where they must, with the common aim of preventing jointly, both stroke and dementia.
\end{abstract}

Keywords: stroke, dementia, prevention

RESUMO

As doenças neurológicas são responsáveis pela maior parte dos Anos de Vida Ajustados por Incapacidade (DALY's) segundo o Estudo da Carga Global de Doença (10\%). Mais da metade dos DALY's de origem neurológica resultam da combinação de acidente vascular cerebral-AVC (42\%) e demência (10\%). Estas duas condições representam risco uma para a outra e compartilham dos mesmos fatores predisponentes. Um AVC quase triplica o risco de demência. Esta grande interação demanda abordagens convergentes. AVC e demência também convergem em nível microscópico. A unidade neurovascular emergiu como estrutura de organização chave da saúde do cérebro. 0 envolvimento de qualquer um dos seus elementos afeta todos os outros. Desse modo, a neurodegeneração compromete a microcirculação, enquanto distúrbios da microcirculação aceleram a neurodegeneração. Novas tecnologias permitem a obtenção de imagens "in vivo" da combinação usual entre patologia vascular e neurodegenerativa de idosos, que os torna vulneráveis ao AVC e à demência. Como estas duas condições ocorrem associadas, devem ser prevenidas em conjunto, com uma abordagem multimodal que conjugue mudanças de hábitos de vida e alvos terapêuticos mecanísticos. Estes dois campos também estão convergindo no campo das políticas de saúde. A Organização Mundial do AVC atualizou sua Proclamação de modo a incluir demências potencialmente passíveis de prevenção, que foi endossada pela Associação Internacional da Doença de Alzheimer, pela Federação Mundial de Neurologia, pela Academia Americana de Neurologia, e por 20 outras organizações internacionais, regionais e nacionais. Os colegas interessados em AVC e aqueles que lidam com demência devem trabalhar juntos onde puderem, diferindo onde devem, com o objetivo comum da prevenção conjunta tanto do AVC quanto da demência.

Palavras-chave: acidente vascular cerebral, demência, prevenção.

\section{THE CONVERGENCE OF STROKE AND DEMENTIA}

Knowledge accrues in pieces but is understood in patterns. Specialization yields the pieces and integration reveals the patterns. The more the fields of stroke and dementia have advanced, the more it becomes obvious that they arise from common bases.

\section{Epidemiology}

Neurological disorders are the leading causes of disability adjusted life years (DALYs) representing $10 \%$ of all causes. Among the neurological disorders, stroke accounts for $42 \%$ and dementia $10 \%$ of the DALYs ${ }^{1}$. Stroke and dementia pose risk for each other. Over the age of 65 years, $64 \%$ of individuals suffering a stroke will have some cognitive impairment

1 Western University, Department of Clinical Neurological Sciences, London, Ontario, Canada.

Correspondence: Vladimir Hachinski; Distinguished University Professor; Department of Clinical Neurological Sciences, Western University; 339 Windermere Road; London, Ontario, Canada, N6A 5A5; E-mail:vladimir.hachinski@lhsc.on.ca

Conflict of interest: There is no conflict of interest to declare.

Received 30 October 2018; Accepted 09 November 2018. 
Table. Main proposed risk and protective factors common for stroke and dementia.

\begin{tabular}{lcc}
\hline Non-modifiable & & Modifiable \\
\hline Risk factors & Risk factors & Protective factors \\
\hline Advanced age & Cerebrovascular disease/stroke & High education \\
Genetic factors (Apo E4) & Cardiovascular diseases & Physical activity \\
Family history & Hypertension & Antihypertensives \\
& Hypercholesterolemia & Statins \\
& Obesity & Active lifestyle \\
& Diabetes & Mediterranean diet (added) \\
& Smoking & \\
\hline
\end{tabular}

Modified from Solomon A et al. JIM 2014 ${ }^{3}$

and among individuals who have some degree of cognitive impairment, a quarter of them have suffered a stroke ${ }^{2}$. Part of the explanation may lie in the fact that stroke and dementia share the same preventable risk factors (Table) ${ }^{3}$.

This may also explain in part why for each stroke or demented patient there are two with some cognitive impairment that puts them at risk of developing stroke, dementia or both ${ }^{2}$. Further evidence for stroke and dementia arising from shared bases comes from the fact that a certain set of subjects is at risk of developing cognitive impairment before and after a stroke ${ }^{4}$.

The incidence and prevalence of dementia is rising in the developing world and falling in the developed world ${ }^{1}$. Although migrants escaping wars, dictatorships, or seeking a better life dominate the news, the number migrating remains too small to affect the fact that the genetics of the world's population has not changed in the past few decades and hence, this divergence must be due to environmental, social and biological factors. One example of how some of these trends can be modified is provided by a study carried out in the Province of Ontario, Canada (population 14 million). In the year 2000, a stroke strategy involving the creation of stroke units, stroke prevention clinics and public campaigns to control risk factors resulted in better outcomes after stroke and transient ischemic attacks ${ }^{5}$. Over a 12 year period, there was a concomitant decrease in the incidence of stroke by $32 \%$ and that of dementia by $7 \%^{6}$. We have a study underway comparing the incidence of stroke and dementia in the provinces in Canada that have a stroke strategy and those provinces that do not, expecting to confirm the findings from Ontario.

\section{Pathophysiology}

Neurons and endothelial cells develop together, feed each other growth factors and eventually develop into a neurovascular unit with the addition of astrocytes, pericytes and macrophages. The neurovascular unit contains the blood brain barrier and is at the core of brain function and failure ${ }^{7}$. Endothelial dysfunction can lead to malnourishment of the neurons and other brain cells and impaired clearance of toxic products from the brain, such as beta amyloid. Correspondingly, a sick neuron secreting beta amyloid oligomers can paralyze the capillaries $^{8}$. It is evident that neurogenerative processes that affect neurons will also have an impact on the microcirculation and vice versa and vascular disease involving the endothelial will affect healthy neurons. Consequently, although unexpected, the study showing that the first step leading to Alzheimer disease of old age is vascular dysregulation is not surprising 9 .

Refinements in magnetic resonance imaging (MRI) techniques are allowing assessment not only of capillary function, but of capillary failure ${ }^{10}$. It is becoming obvious that we cannot understand neurodegeneration without understanding the microcirculation or the microcirculation without understanding neurodegenerative processes.

Evidence is also accumulating in support of the concept that cerebral ischemia is an accelerated form of neurodegeneration $^{11}$. The hopeful part of this concept is that some of the so called neuroprotectants used in acute stroke may not have been powerful enough to overcome the massive disturbance of brain tissue of an acute brain infarct, but they may find a role in mitigating slower vascular pathophysiological processes.

\section{Diagnosis}

Appropriately, the urgency of a transient ischemic attack or the potential catastrophe of a stroke dominate the attention of stroke doctors. However, this has detracted from the realization that the most common consequence of cerebral vascular disease is not stroke, but cognitive impairment. For every clinical stroke there are about 5 so called "silent strokes" that are asymptomatic, but if the patients are examined, they often have mild neurological signs, decrease in processing speed and some cognitive impairment, particularly in executive function ${ }^{12}$. 


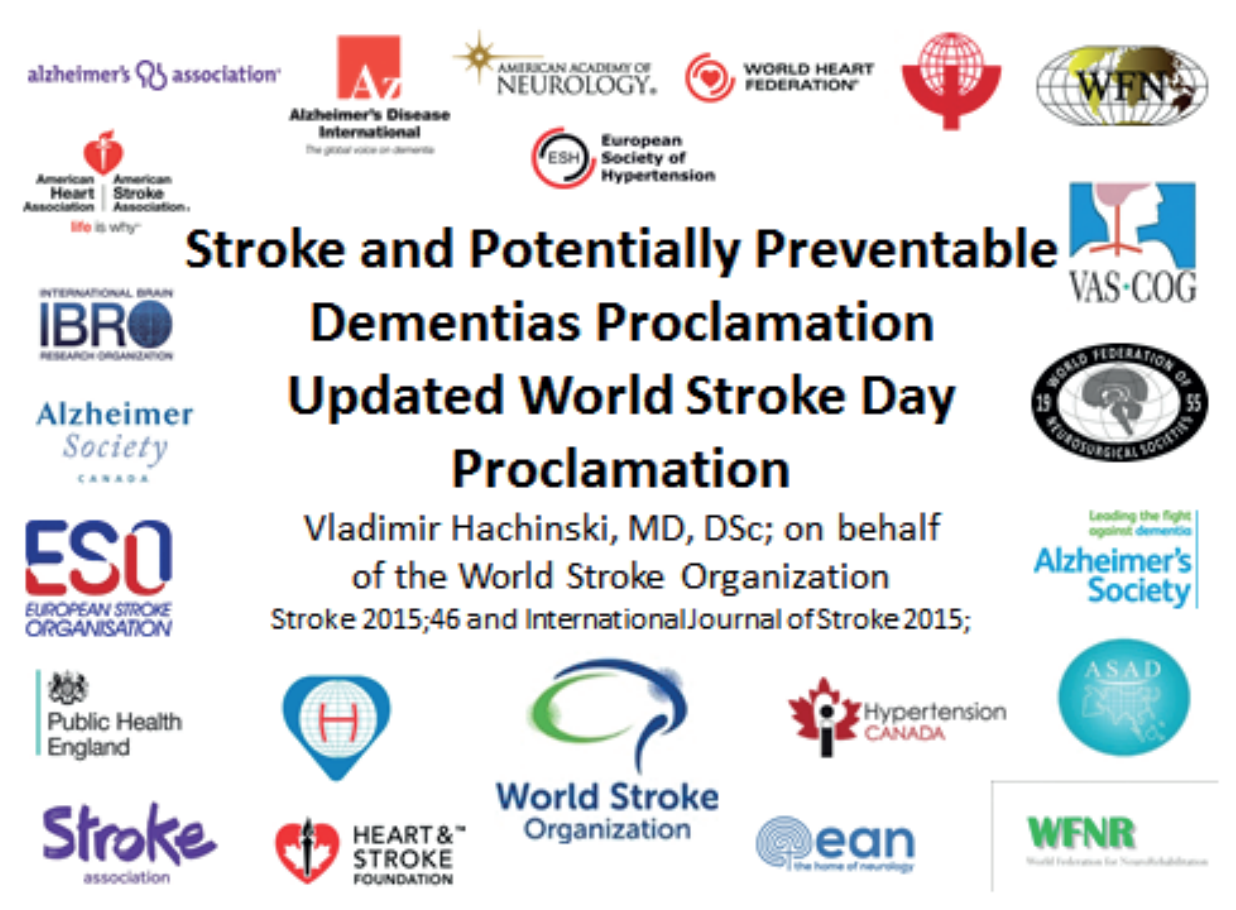

Figure. List of Proclamation Endorsers ${ }^{15}$.

Encouragingly, brain imaging has advanced enough not only to detect small cortical infarcts, but also microbleeds. Additionally we have come to realize that white matter changes to the brain are a prelude not only to stroke, but to dementia ${ }^{13}$. Although positron emission tomography (PET) techniques are too expensive and unavailable for daily practice, they do provide the tools whereby we can begin looking at interactive brain mechanisms, correlating structural and functional magnetic resonance imaging with the ability to detect amyloid, inflammation and now tau protein depositions paving the way to move from muddled diagnosis to treatable mechanisms ${ }^{14}$.

\section{Treatment}

Treating stroke patients in stroke units and providing for those that qualify for thrombolysis and thrombectomy is worthwhile in itself. It will not be long before it is shown that this also affects favorably the cognitive preservation in these patients, an important factor in rehabilitation and enjoyment of life.

\section{Prevention}

Since stroke and dementia occur together, it makes sense to try and prevent them together. The Proclamation of the World Stroke Organization updated in 2015 and endorsed by all the major organizations dealing with the brain, stroke and dementia ${ }^{15}$ (Figure).

The World Stroke Organization, the World Heart Federation, the World Hypertension League and European Society of Hypertension have agreed to work closely in implementing the joint prevention of stroke and potentially preventable dementia. ${ }^{16}$ Moreover, a session at the World Health Summit preceded by a one day satellite meeting reviewed, summarized and evaluated the scientific bases for considering stroke and dementia jointly. (https://www.worldhealthsummit.org) (https://www.worldhealthsummit.org/satellites/ dementia-stroke-prevention.html) An article to be published in Alzheimer's \& Dementia will summarize the results, recommendations and serve as a guide for implementing policy.

\section{CONCLUSION}

Stroke and dementia share the same risk factors, pose risks for each other, tend to occur together, interact pathophysiologically and preventing stroke might prevent some dementias.

Strength will arise from the union of the two fields. To paraphrase the motto of Acadia (a part of Canada) "L'union fait la force".
2. Jin YP, Di Legge S, Ostbye T, Feightner JW. Hachinski V. The reciprocal risks of stroke and cognitive impairment in an elderly population. Alzheimer's \& Dementia. 2(3):171-178, 2006 
3. Solomon A, Mangialasche F, Richard E, Andrieu S, Bennett DA, Breteler M, Fratiglioni L, Hooshmand B, Khachaturian AS, Schneider LS, Skoog I, Kivipelto M. Advances in the prevention of Alzheimer's disease and dementia. J Intern Med. 2014 Mar;275(3):229-50

4. Guo X, Ostling S, Kern S, Lohansson L, Skoog I. Increased risk for dementia both before and after stroke: A population-based study in women followed over 44 years. Alz \& Dement. 2018;14:1253-1260

5. Webster F, Saposnik G, Kapral M, Fung J, O'Callaghan C, Hachinski V. Organized Outpatient Care. Stroke prevention clinical referrals are associated with reduced mortality after transient ischemic attack and ischemic stroke. Stroke. 2011;42:3176-3182

6. Sposato LA, Kapral MK, Wu J, Gill SS, Hackam DG, Cipriano LE, Hachinski V. Declining incidence of stroke and dementia: Coincidence or prevention opportunity? JAMA Neurol. 2015:72;1529-1531

7. Sweeney MD, et al. Vascular dysfunction - The disregarded partner of Alzheimer's disease. Alz \& Dement 2018 (in press)

8. Iadecola C. The pathobiology of vascular dementia. Neuron 2013;80:844-66.

9. Y Iturria-Medina, RC Sotero, PJ Toussaint, JM Matteos-Perez, AC Evans \& The Alzheimer's Disease Neuroimaging Initiative. Early role of vascular dysregulation on late-onset Alzheimer's disease based on multifactorial data-driven analysis. Nature Comm. 2016;7:11934

10. Nielsen RB, Egefjord L, Angleys H, Mouridsen K, Gejl M, Moller A, et al. Capillary dysfunction is associated with symptom severity and neurodegeneration in Alzheimer's disease. Alzheimer's \& Dement. 2017;13:1143-1153.

11. Alzheimer's Association Calcium Hypothesis Workgroup. Calcium hypothesis of Alzheimer's disease and brain aging: A framework for integrating new evidence into a comprehensive theory of pathogenesis. Alzheimer's \& Dementia. 2017;13:178-182

12. Vermeer SE, Prins, ND, Heijer TD, Hofman A, Koudstaal PJ. Breteler MMB. Silent brain infarcts and the risk of dementia and cognitive decline. NEJM 2003;348:1215-1222

13. Lee S, Viqar F, Zimmerman ME, Narkhede A, Tosto G, Benzinger TL, Marcus D, Fagan AM et al. Dominantly Inherited Alzheimer Network. White matter hyperintensities are a core feature of Alzheimer's disease: Evidence from the dominantly inherited Alzheimer network. Ann Neurol. 2016 79:929-39.

14. Hachinski V, Sposato L. Scientific Comment. Dementia: from muddled diagnoses to treatable mechanisms. Brain 2013;136:2652-2656

15. Hachinski V on behalf of the World Stroke Organization. Stroke and potentially preventable dementias. Proclamation updated World Stroke Day Proclamation. Stroke. 2015:46;3039-3040

16. Hachinski V, Ganten D, Lackland D, Kreutz R, Tsioufis K, Hacke W on behalf of the World Stroke Organization, the World Heart Federation, the World Hypertension League and the European Society of Hypertension. Implementing the proclamation of stroke and potentially preventable dementias. Int J of Stroke. 2018;13:780-786 